\title{
A New Approach to Using the Old Greek in Hebrew Bible Textual Criticism*
}

John Screnock

\begin{abstract}
Emanuel Tov's published methodology for using the Old Greek in textual criticism of the Hebrew Bible has been the gold standard for all such methods and has pushed scholars to make better use of the Old Greek. In this essay, I present a new approach by building on Tov's methodology. Although Tov accounts for the reality of Hebrew variants within the mind of the translator and furthermore recognizes the impossibility of isolating such variants, he explores the idea only with regards to scribal errors, leaving most changes stemming from "contextual exegesis" to be categorized as inner-translational and thus inadmissible in the text critical endeavor. I argue for an extension of Tov's method by considering other possible ways in which a scribe working in Hebrew could have made the changes commonly attributed to the translator. In contrast to Tov's method, I suggest we center our use of the Old Greek in textual criticism around one main criterion (though some exceptions to this rule remain): if Hebrew can be reconstructed on the basis of clear translation patterns, the evidence should be used in textual criticism.
\end{abstract}

\section{Keywords}

Textual criticism, Septuagint, Old Greek, Text-critical use of the Septuagint

\section{Introduction}

Translation from Hebrew to Greek in the ancient world was complicated; the process of unearthing text-critical data behind that translation is perhaps more complicated. Emanuel Tov's methodology using the Old Greek (OG) for textual criticism of the Hebrew Bible (HB) is the gold standard for all such methodologies. The principles he lays out, particularly in Text-Critical Use of the Septuagint in Biblical Research, ${ }^{1}$ have been followed by a generation of text-critics. In this essay, I argue for an extension of Tov's method, focusing on the notion that we can isolate changes to the Hebrew text that stem from the translator. This principle, articulated by most scholars working in the area, is a good principle; in HB textual criticism we are looking for variant Hebrew readings, not phenomena that occur in translation - though those phenomena are of course worthy of study in their own right. If the OG reading arises in the process of translation, it must

* I thank Gene Ulrich for his valuable feedback on a previous draft of this study, and participants in the "Horizons in Textual Criticism" colloquium, held in Oxford in 2017, for their spirited engagement.

1 Emanuel Tov, Text-Critical Use of the Septuagint in Biblical Research, 3d ed. (Winona Lake, Ind.: Eisenbrauns, 2014). 
not reflect a variant Hebrew source — goes the reasoning — and therefore it is not relevant.

Although this sensible principle seems almost self-evident, I would like to question it. How possible it is for us to distinguish changes made in translation from variations arising in the transmission of the Hebrew text? ${ }^{2}$ We know that the OG translators did many of the same things as scribes who copied the same texts in Hebrew. We know, for example, that they sometimes committed a scribal error, and that they sometimes changed the text in order to clarify its interpretation. Indeed, when one compares descriptions of scribal change in transmission to the changes made in translation in the OG, many of the phenomena are the same. ${ }^{3}$ It is difficult to identify a reliable basisaside from "scholarly intuition" — on which to distinguish between differences in the OG that arose in translation and those that reflect a Hebrew Vorlage with differences arising in transmission. As a result, we are often confronted with a choice: use data from the OG and thereby risk the inclusion of translator induced changes, or disqualify data from the OG and thereby risk throwing away valuable evidence. In the case of scribal errors generally, Emanuel Tov opts for the former, stating, "One simply has to accept the fact that some reliable retroversions never existed in writing." ${ }^{4}$ argue that we should apply Tov's pragmatic acceptance more broadly still, so that it covers any type of translator induced change that cannot reliably be distinguished from scribal activity in Hebrew.

After a brief summary of Tov's methodology for using the OG in HB textual criticism - which represents the current consensus in the field-I argue for new ways in which we should open up Tov's method and propose a different procedure for treating OG evidence. Many of my examples come from Ps 104, a text for which I am currently preparing a critical edition.

\section{Emanuel Tov's Methodology}

Tov's work on the use of the OG in HB textual criticism-articulated most fully in his Text-Critical Use of the Septuagint-has dominated the field in recent decades and shaped the approaches of other text-critics and Septuagintalists, myself included. ${ }^{5}$ Like

2 This is by no means a new question; for example, M. H. Goshen-Gottstein's "Theory and Practice of Textual Criticism: The Text-critical Use of the Septuagint," Textus 3 (1963): 130-58, focuses entirely on this question in the context of an edition of the Hebrew Bible with critical apparatus.

3 See, for example, Emanuel Tov, Textual Criticism of the Hebrew Bible, 3d ed. (Minneapolis: Fortress Press, 2012), 119-22 (on ancient translations like the OG) and 240-62 (on transmission of the Hebrew text).

4 Tov, Text-Critical Use of the Septuagint, 178. Goshen-Gottstein's solution to this problem was "double notation"-listing in the apparatus both the "mechanical retroversion" and "interpretive retroversion" of the OG; the former follows mechanical isomorphisms and results in a variant, while the latter seeks to explain the difference between the OG and the Hebrew as interpretation occurring in the process of translation; "Theory and Practice," 133-34 and throughout.

5 For a history of scholarship on this issue before publication of Tov's Text-Critical Use of the Septuagint, see Natalio Fernández Marcos, "The Use of the Septuagint in the Criticism of the Hebrew 
many scholars whose work has been affected by the discovery of the Dead Sea scrolls, Tov has pushed for a greater appreciation of the OG as a text-critical witness to the HB.

Tov distinguishes two primary aspects to finding text-critical data in the OG, which I will address in turn: determining whether the Greek reflects a variant Hebrew reading, and retroverting the Hebrew behind the Greek. ${ }^{6}$

\subsection{Inner-translational Factors}

Tov observes that not all "deviations" between the OG and Hebrew source stem from a variant Vorlage. ${ }^{7}$ Rather, many deviations are "inner-translational," whether stemming from the process of translation, or from scribal developments within the transmission of the Greek text. ${ }^{8}$ The latter have no text-critical value for HB textual criticism, inasmuch as they arise without any reference to the Hebrew. ${ }^{9}$

Tov appeals to two concepts of "exegesis" to describe many inner-translational differences. ${ }^{10}$ "Linguistic exegesis" refers to the basic understanding of the source text,

Bible," Sefarad 47 (1987): 59-72.

6 This typology is reflected in the organization of material in Part One of Text-Critical Use of the Septuagint: chapter two considers "When to Reconstruct Variants," while chapters three and four discuss "How to Reconstruct the Vorlage of the LXX." Tov also discusses how the retroverted Hebrew of the OG relates to other text-critical data in Part Two, but this has no bearing on my discussion here; cf. Text-Critical Use of the Septuagint, 4.

7 Text-Critical Use of the Septuagint, 43. Tov uses the term "deviation in the widest sense, including the smallest dissimilarities"; ibid. It is clear, however, that he does not intend to include the many basic differences between the OG and Hebrew source. For example, he would not take àví $\rho$, "man," to constitute a divergence from "xִ, "man," though in fact the two are very different (in phonology, graphic representation, etc.). Rather, Tov means deviations beyond what is involved in a basic, moreor-less isomorphic translation of Hebrew into Greek.

8 Text-Critical Use of the Septuagint, 44, 49.

9 Text-Critical Use of the Septuagint, 44, 49, 55-60, 88-89. See also James Barr, Comparative Philology and the Text of the Old Testament (Oxford: Clarendon, 1968), 247-48; John William Wevers, "The Use of the Versions for Text Criticism: The Septuagint," in La Septuaginta en la Investigación Contemporánea (V Congreso de la IOSCS), ed. Natalia Fernández Marcos (Madrid: Instituto Arias Montano, 1985), 19-20; Anneli Aejmelaeus, On the Trail of the Septuagint Translators: Collected Essays, CBET 50 (Leuven: Peeters, 2007), 72, 74-75; Tov, Textual Criticism, 122; Peter Gentry, "The Septuagint and the Text of the Old Testament," BBR 16 (2006): 195-96.

10 Though Tov is careful to define what he means by "exegesis," it is perhaps not the best term given that it usually refers to critical interpretation of a text. Nevertheless, because I begin with Tov I will use his terminology throughout the study for consistency. For similar uses of the term, cf. Max Margolis, "Complete Induction for the Identification of the Vocabulary in the Greek Versions of the Old Testament with Its Semitic Equivalents: Its Necessity and the Means of Obtaining It," JAOS 30 (1910): 302; Goshen-Gottstein, “Theory and Practice," 131-32. Contra James Barr, The Typology of Literalism in Ancient Biblical Translations, MSU 15 (Göttingen: Vandenhoeck \& Ruprecht, 1979), 292-93, all translation does involve some level of interpretation; see Birgitta Englund Dimitrova, “Translation Process," 406, and Radegundis Stolze, "Hermeneutics and Translation," 141, both in 
"the grammatical identification of all words ... as well as their semantic interpretation." 11 We might call this "decoding," with Aejmelaeus, or simply "reading," if we think the translator was competent enough to read a Hebrew text without the help of an intentional and methodical grammatical analysis. ${ }^{12}$ "Contextual exegesis" relates to all nonlinguistic issues, "renderings that deviate from the literal sense of a given Hebrew word, phrase or sentence." ${ }^{\prime 3}$ In Textual Criticism, Tov adds "theological" and "midrashic" as two further types of non-linguistic exegesis. ${ }^{14}$

The potential for the translator to make a scribal error when reading the Hebrew is a well-documented phenomenon that can eliminate $\mathrm{OG}$ evidence from $\mathrm{HB}$ textual criticism. ${ }^{15}$ In this particular area, Tov fruitfully explores our ability to discern which variants stem from the translator and which from his Vorlage (see below). A final factor discussed by Tov is not a cause for "deviation" but a potential cause for modern readers

Handbook of Translation Studies: Volume 1, eds. Yves Gambier and Luc van Doorslaer (Amsterdam: John Benjamins, 2010). However, that OG translation involves interpretation does not entail necessarily that it has a "distinct exegetical character" (Goshen-Gottstein, "Theory and Practice," 131).

11 Text-Critical Use of the Septuagint, 49-50, quote from 50. See also Tov, Textual Criticism, 118-19; Bénédicte Lemmelijn, A Plague of Texts? A Text-Critical Study of the So-Called 'Plague Narrative' in Exodus 7:14-11:10, OtSt 56 (Leiden: Brill, 2009), 98-99.

12 On decoding, see Aejmelaeus, On the Trail, throughout. On whether translators simply read the Hebrew or began with a segmented analysis - as described in James Barr, "Vocalization and the Analysis of Hebrew among Ancient Translations," in Hebräische Wortforschung: Festschrift zum 80. Geburtstage von Walter Baumgartner, eds. Benedikt Hartmann et al, VTSup 16 (Leiden: Brill, 1967), 1-11, and Tov, Textual Criticism, 118-19-see my summary and critique in Traductor Scriptor: The Old Greek Translation of Exodus 1-14 as Scribal Activity, VTSup 174 (Leiden: Brill, 2017), 82-84.

13 Text-Critical Use of the Septuagint, 50-55, quote from 50. Note again that here Tov assumes a "literal" baseline mode of translation, as described in Text-Critical Use of the Septuagint, 18-32, but one might object that other modes of translation have equal claim to representing the "literal sense" of the source text: if a translation opted to represent the argument structure of a verb, the precise semantics of a lexeme, or the poetic features of the source text, for example, it may very well need to sacrifice the sort of morphological isomorphism that is typically equated with "literal," but it would be no less literal in my opinion. See also Tov, Textual Criticism, 119-22; Lemmelijn, A Plague of Texts?, 99; Jobes and Silva, Invitation to the Septuagint, 153; Gentry, "The Septuagint and the Text of the Old Testament," 201-202. For important limitations on this type of explanation, see Albert Pietersma, "Exegesis in the Septuagint: Possibilities and Limits (The Psalter as a Case in Point)," in Septuagint Research: Issues and Challenges in the Study of the Greek Jewish Scriptures, eds. Wolfgang Kraus and R. Glenn Wooden, SCS 53 (Atlanta: Society of Biblical Literature, 2006), 33-45; and cf. Pietersma, "Messianism and the Greek Psalter: In Search of the Messiah," in The Septuagint and Messianism, ed. Michael Anthony Knibb, BETL 195 (Leuven: Peeters, 2006), 50-52.

14 On theological exegesis, Tov, Textual Criticism, 120-22; on midrashic interpretation, Tov, Textual Criticism, 122.

15 Tov, Text-Critical Use of the Septuagint, 55-60; Aejmelaeus, On the Trail, 80; Jobes and Silva, Invitation to the Septuagint, 153. 
to misunderstand the Greek as deviating. One can safely identify deviation only when the translation technique of the particular OG book is understood. ${ }^{16}$ Tov follows a typology of translation technique which plots translation on a spectrum between "literal" and "free." 17 Though not all would agree with Tov's idea of OG translation technique, ${ }^{18}$ most would agree with the basic notion that some translation styles more transparently reflect their source than others - with repercussions for their usefulness in HB textual criticism-and that the OG's translation technique is crucial to the text-critical enterprise. $^{19}$

Most methodologies involve a typology of factors similar to Tov's for eliminating OG data from use in HB textual criticism-inner-OG textual transmission, contextual exegesis (interpretation), linguistic exegesis (decoding), translator scribal error, and translation technique. ${ }^{20}$

\subsection{Reconstruction of Hebrew}

When a piece of OG data survives the test, as it were, and is not eliminated based on these factors, the next step in the methodology is to retrovert the Hebrew behind the Greek. In practice, however, the step of retroversion occurs simultaneously alongside the consideration of the factors noted above. ${ }^{21}$ When treating OG evidence, the text-critic both retroverts possible Hebrew Vorlagen and considers the other factors of Tov's typology, looking in all of these for the best explanation of the OG data.

Tov's extensive discussion of retroversion has many facets. ${ }^{22}$ Tov notes that

16 Text-Critical Use of the Septuagint, 18, 48-49. See also Margolis, "Identification of Vocabulary," 302303; Wevers, "The Use of the Versions," 20-24; Aejmelaeus, On the Trail, 72-73; Lemmelijn, A Plague of Texts?, 19, 23-24, 103-104; Barr, Comparative Philology, 250-59.

17 See Tov, Text-Critical Use of the Septuagint, 18-32. Although there are other concepts that better describe the dynamics at play-for example, functional versus dynamic, source oriented versus target oriented, or covert versus overt - the traditional literal versus free are sufficient for Tov's discussion. See Eugene A. Nida and Charles R. Taber, The Theory and Practice of Translation, With Special Reference to Bible Translating, Helps for Translators 8 (Leiden: Brill, 1969); Gideon Toury, Descriptive Translation Studies and Beyond, Benjamins Translation Library 4 (Amsterdam: John Benjamins, 1984); Juliane House, "Overt and Covert Translation," in Handbook of Translation Studies, 245-46.

18 See Screnock, Traductor Scriptor, 25-31.

19 See Tov, Text-Critical Use of the Septuagint, 64, 66, 96; Wevers, "The Use of the Versions," 20-21; Aejmelaeus, On the Trail, 72-74, 76-77; Lemmelijn, A Plague of Texts?, 19, 97, 130-31; Screnock, Traductor Scriptor, 25-31, 73-76.

20 See Screnock, Traductor Scriptor, 31-39.

21 "When analyzing the text-critical value of [differences between Greek and Hebrew witnesses], one constantly oscillates between the assumption of inner-Septuagintal factors ... and underlying Hebrew variants. This problem is the focus of the text-critical analysis of the [OG]"; Tov, Text-Critical Use of the Septuagint, 48.

22 Like Tov's inner-translational factors, criteria for retroversion are pertinent to the question of what OG evidence is allowed into HB textual criticism. We cannot use the OG for textual criticism if we cannot 
"literal" translations make retroversion more possible, while "freer" translations make retroversion less plausible or even impossible. ${ }^{23}$ Retroversions should be based on vocabulary equivalences that can be established from evidence in the rest of the OG, whenever possible. ${ }^{24}$ Tov does not mean, however, that we should follow the most common lexical equivalence(s); "infrequently used" glosses may also be used. Grammatical words, morphosyntactic features, and syntax are difficult to reconstruct, and should only be retroverted in the most isomorphic translations. ${ }^{25}$ When there are not sufficient data available to establish a vocabulary equivalence, retroversions can be "based on the scholar's intuition." 26 Reconstructions, whether based on vocabulary equivalences or scholarly intuition, should meet two further criteria or "precondition(s) for correct retroversion." 27 These are that the retroversion should fit within the context of the rest of the textual $\operatorname{data}^{28}$ and should be characteristic or at least fitting of the "grammar, vocabulary and style" of the Hebrew text. ${ }^{29}$ Retroversions have added weight if they align with readings in extant Hebrew witnesses, but this is not a criterion for the plausibility of the retroversion. ${ }^{30}$

In multiple places, Tov discusses a point close to my focus in following sections: Hebrew variants could easily stem from the translator's mind rather than from a Hebrew Vorlage, and very often we cannot tell the difference between the two. ${ }^{31}$ By the term "variant," Tov means any Hebrew reading-from a Hebrew manuscript or retroverted from a translation - that differs from the MT. ${ }^{32}$ Crucially, retroverted OG readings qualify as "variants" even if they arose only in the mind of the translator. ${ }^{33}$ In the

reconstruct it, and reconstructions that align with extant Hebrew witnesses - most significantly, the MT_-are of less significance for HB textual criticism.

23 Tov, Text-Critical Use of the Septuagint, 64, 66, 96.

24 Tov, Text-Critical Use of the Septuagint, 65-66; cf. Margolis, "Identification of Vocabulary," throughout.

25 Tov, Text-Critical Use of the Septuagint, 64; see also 170-78. Tov seems to qualify this notion on pages 75-78, however, where he notes and lists around 50 studies that chart the translation technique of the OG with respect to syntax and grammar-implying that there are a good number of grammatical aspects we can reconstruct of the basis of the Greek.

26 Tov, Text-Critical Use of the Septuagint, 78-80.

27 Tov, Text-Critical Use of the Septuagint, 64, quoted text from 84.

28 They should "be probable from a textual point of view"; Tov, Text-Critical Use of the Septuagint, 64, and see 81-83; cf. similarly Margolis, "Identification of Vocabulary," 303.

29 Tov, Text-Critical Use of the Septuagint, 65, 84-86; and cf. Margolis, "Identification of Vocabulary," 303. One exception to the latter criterion is when a retroversion is secondary from a text-critical point of view, and thus would not be expected to fit the characteristics of the Hebrew text; Tov, Text-Critical Use of the Septuagint, 84.

30 Tov, Text-Critical Use of the Septuagint, 87-88.

31 Tov, Text-Critical Use of the Septuagint, 98-99, 134, 178.

32 Tov, Text-Critical Use of the Septuagint, 5, 134-35.

33 "Due to lack of suitable controls, retroverted variants that existed only in the mind of a translator are also called variants"; Tov, Text-Critical Use of the Septuagint, 99; see also 134, 178. 
exceptional cases where we can discern that a retroverted Hebrew variant comes from the translator's mind, these are termed "pseudo-variants" and excluded from text-critical use. Although the distinction between a retroverted "variant" from the translator's mind and "pseudo-variant" is our ability to identify the latter but not the former, "recognition of a pseudo-variant is [largely] subjective." 34

Tov's methodology results in three distinct kinds of evidence where the OG differs from the MT: (1) differences stemming from inner-translational factors; (2) retroverted variants, which may stem from the Hebrew Vorlage or from the translator's mind; (3) pseudo-variants, which we can identify as stemming from the translator's mind. It is essential to note that Tov's idea of variants from the translator's mind are tied to scribal error, while phenomena related to contextual or linguistic exegesis are not possible as retrovertable Hebrew variants. ${ }^{35}$ The point can be deduced from several places: all of Tov's examples of retroversion based on lexical equivalence involve scribal error; ${ }^{36}$ elsewhere, Tov's analysis implies that contextual exegesis in the OG should always be attributed to the Greek level of the text. ${ }^{37} \mathrm{OG}$ readings that are explained as contextual or linguistic exegesis are typically not able to be considered variants, because they do not make it to Tov's step of retroversion. The exceptions ${ }^{38}$ prove the rule: Tov does not allow for the possibility of translator-induced Hebrew variants in the realm of contextual exegesis. Tov applies his compelling notion about Hebrew in the mind of the translator to cases involving scribal error, then, but not to contextual or linguistic exegesis.

\section{$2 \quad$ Beyond Tov's Methodology}

Methodological studies published after Tov's Text-Critical Use of the Septuagint first appeared in 1981 - for example, Anneli Aejmelaeus's "What can We Know about the Hebrew Vorlage of the Septuagint?," Peter Gentry's “The Septuagint and the Text of the Old Testament," and Bénédicte Lemmelijn's A Plague of Texts? ${ }^{39}$ - follow the same

34 Tov, Text-Critical Use of the Septuagint, 178.

35 The same methodology is evident in Goshen-Gottstein's "double notation" (in "Theory and Practice," throughout): the "interpretive" explanation always assumes that the translator is responsible for the interpretation, though in fact scribes working in Hebrew made the same sorts of changes.

36 That is, excluding his examples for reconstructing a long string of text that has no counterpart in any extant Hebrew witness. Tov, Text-Critical Use of the Septuagint, 66-70.

37 See, for example, Tov, Text-Critical Use of the Septuagint, 92, where a retroversion based on graphic interchange is legitimate "as long as $\sigma \nu v \tau \varepsilon \tau \rho \mu \mu \varepsilon v o \varsigma$ is not considered an exegetically motivated rendering."

38 Exceptions include cases where contextual exegesis is found in the form of a Hebraism, where Tov reasons that OG translators would not introduce Hebraisms, and therefore they must reflect the Hebrew Vorlage; Tov, Text-Critical Use of the Septuagint, 93. Similarly, retroversions are considered more "reliable" if they reflect a better/earlier reading (or scribal errors in Hebrew) — only possible if they stem from a Hebrew Vorlage; Tov, Text-Critical Use of the Septuagint, 95.

39 Anneli Aejmelaeus, "What Can We Know about the Hebrew Vorlage of the Septuagint?" (first published in 1987), pages 71-106 in On the Trail. Peter Gentry, "The Septuagint and the Text of the 
principles articulated by Tov to varying degrees, including the idea that translator induced change can be discerned. ${ }^{40}$ Tov and others are surely right to believe that translators made changes to the text as a result of contextual and linguistic exegesis. These scholars, moreover, are careful to note that translator-made and scribe-made changes resemble one another. There is often an underlying assumption, however, that scribes are better at handling the text than translators. ${ }^{41}$ More significantly, the general framework in which data are analyzed skews in the direction of dismissal of OG evidence: the reader is given an extensive list of ways in which the OG could have altered the text, thereby disqualifying the evidence. ${ }^{42}$ This imbalance is not offset by the clarification that we often cannot tell if these processes belong to the OG or to the Hebrew Vorlage when the translation is Hebraistic. While I agree that there are some cases where we can assign a divergence to the translator with a good degree of certainty, I would argue that our default position should start with isomorphic, Hebraised Greek as representing a Hebrew Vorlage, and the burden of proof should fall on an argument that sees the divergence as translational. Such an approach would push scholars and students to an increased use of the OG in textual criticism. Finally, perhaps most egregious is the notion, found in varying degrees, that the OG should be viewed as translating the MT if it is at all possible. ${ }^{43}$ On the contrary, if it is possible to see the OG as having translated

Old Testament," BBR 16 (2006): 193-218; Bénédicte Lemmelijn, A Plague of Texts? A Text-Critical Study of the So-Called 'Plague Narrative' in Exodus 7:14-11:10, OtSt 56 (Leiden: Brill, 2009).

40 Aejmelaeus (and Lemmelijn following her) are more willing than Tov to see content related differences in the OG as stemming from a Hebrew source; Aejmelaeus, On the Trail, 81. However, both maintain that we can distinguish interpretive and explicating changes made to the text in translation from similar changes made by scribes in Hebrew; Lemmelijn, A Plague of Texts?, 99-103.

41 Tov sometimes acknowledges this assumption; see Text-Critical Use of the Septuagint, 183. Gentry, for example, while being careful to give explicit arguments that examples derive from translation rather than a Hebrew Vorlage, seems to hold an underlying assumption that translators were susceptible to certain pressures that scribes were not. The influence of later dialects and concordance with later interpretive tradition are both taken as sure signs that the translator was responsible for a change, though one might argue that late Second Temple scribes experienced the same influences and were themselves willing to make the same changes in the Hebrew text; Gentry, "The Septuagint and the Text of the Old Testament," 200-202.

42 Cf., e.g., Barr, Comparative Philology, 245.

43 See, for example, John William Wevers, Notes on the Greek Text of Leviticus, SBLSCS 44 (Atlanta: Scholars Press, 1997), 438. Aejmelaeus states, "It should ... be possible to answer the question whether or not it would have been possible to arrive at the translation at hand from a text identical with the MT. If the answer is yes, the case is text-critically irrelevant." On the Trail, 79. Tov writes that "Only after all possible translational explanations have been dismissed should one address the assumption that the translation represents a Hebrew reading different from MT"; moreover, "Cautious scholarship attempts to delay the assumption of underlying variants as long as possible"; Text-Critical Use of the Septuagint, 44. When the MT is taken as the point of departure for analysis of the OG (see Text-Critical Use of the Septuagint, 5), notions of cautious scholarship and constraint serve to prejudice the process toward aligning the OG evidence with the MT. Against this MT-centricism, see 
the MT but not probable based on translation patterns, there is no reason to align the OG's Vorlage to the MT.

In contrast to these approaches, I suggest that we begin with the assumption that OG divergences represent a Hebrew text; the OG data is "innocent until proven guilty." Moreover, I argue that we should expand our use of Tov's idea that Hebrew variants can occur in the mind of the translator.

\subsection{Could a Scribe Have Done the Same? From Assumption of Greek Change to Assumption of Hebrew Variation}

When we encounter OG evidence that can be explained by Tov's categories of innertranslational change, I suggest that we ask ourselves whether a scribe transmitting the text in Hebrew could have potentially made the same change. The first case Tov cites of contextual exegesis, ${ }^{44}$ for example, could just as well have been made by a scribe:

Figure 1-Genesis 9:22

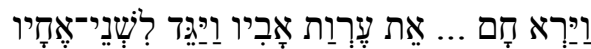

And Ham saw ... the nakedness of his father, and he made it known to his two brothers.

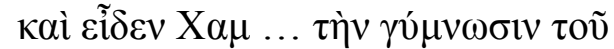

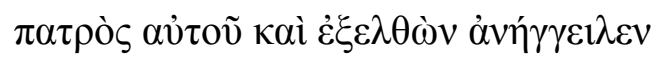

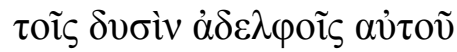
And Cham ... saw the nakedness of his father, and after he had gone out he told his two brothers. (NETS)

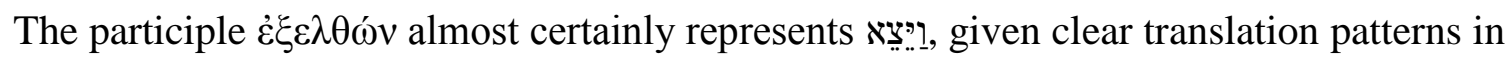
the rest of OG Genesis and other OG pentateuchal texts. ${ }^{45}$ If we view the OG evidence as secondary-required for Tov's analysis that this is contextual exegesis on the part of the translator - the reason for the change seems clear enough: Ham must have been (in the scribe/translator's mind) inside the tent when he saw his father, and would have had to exit the tent in order to tell his brothers outside. Could not a Hebrew scribe, following the same logic, have changed the text by adding ויצא? Whether or not the reading is secondary, we should not assume that it stems from the translator by virtue of its being contextual exegesis. ${ }^{46}$ Others have clearly articulated this point with respect to cases Tov might categorize as contextual exegesis. ${ }^{47}$

James Barr, review of Karen H. Jobes and Moises Silva, Invitation to the Septuagint, Review of Biblical Literature [http://www.bookreviews.org] (2002).

44 Tov, Text-Critical Use of the Septuagint, 51.

45 On the participle for a wayyiqtol, see Aejmelaeus, On the Trail, 5; on the equivalence of $\dot{\varepsilon} \xi \dot{\varepsilon} \rho \chi 0 \mu \alpha \mathrm{r}$ and

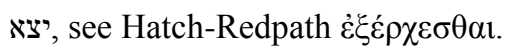

46 Here I contrast two options for explaining the data-the translator changing the text or a scribe changing the text - but a third option should be kept in mind, namely, that the OG reflects a Hebrew reading that is earlier, in which case the only change involved is within the text witnessed in the MT.

47 E.g., Aejmelaeus, On the Trail, 81-85; Aejmelaeus concludes that "the scholar who wishes to attribute 
While content changes are the most obvious place to test whether a scribe could have made the same change, the point can also apply to cases that might be explained as translation technique or even textual development within transmission of the OG. On

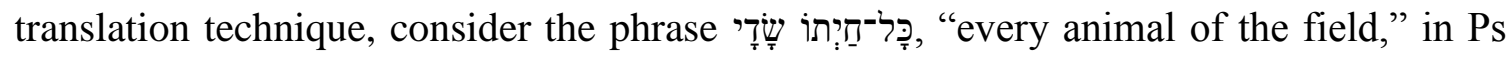
104:11. The atypical form חיתו is consonantally identical to a bound singular noun with a clitic pronoun, but is in fact a poetic form of singular חָ חָָָּ used in the Psalms and

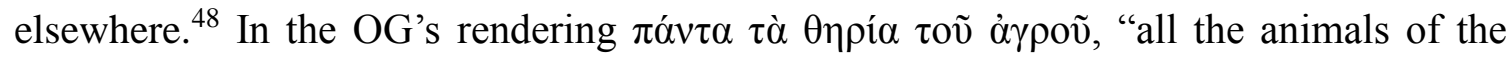
field" (NETS), the difference between plural "all animals" and singular "every animal" is slight. It is possible that the translator struggled with the atypical form and "manipulated" (to use Tov's term) ${ }^{49}$ the consonantal text slightly so that he read plural חיות by transposition of taw and waw. ${ }^{50}$ This appears on first sight, then, to be a clear case of translation technique; and I should note that, in the final analysis, the difference is simply a factor of translation technique. However, we learn valuable information when we ask whether a scribe could have made the same change. When we do so, we note that the form חיתו could have been difficult to a Second Temple scribe as well, who could have made a similar alteration to plural חיות to ameliorate the difficulty. ${ }^{51}$ Moreover, a Hebrew witness, $4 \mathrm{QPs}^{\mathrm{d}}$, makes precisely the same change at precisely the same point, reading here, indicating that scribes were in fact capable of doing the same thing with the text. My point here is not to argue that the plural $\tau \grave{\alpha} \theta \eta \rho i ́ \alpha$ in fact stems from a variant Vorlage, for it does not (see below); rather, I mean to point out that it is always profitable to ask whether a scribe may have made the same change evidenced in the OG.

Although our process should begin with an assumption that the change could have occurred in Hebrew, it is crucial to investigate the translation data carefully. Despite the reading חיות in $4 \mathrm{QPs}^{\mathrm{d}}$, the balance of probability shifts back to translational factors מעינו Pecause these poetic forms - חיתו Phether 50:10; 79:2; 104:11, 20) or similar (Ps 114:8) - are always rendered as plurals in the OG. ${ }^{52}$ If the other cases of

deliberate changes, harmonizations, completion of details and new accents to the translator is under the obligation to prove his thesis with weighty arguments and also to show why the divergences cannot have originated with the Vorlage. That the translator may have manipulated his original does not mean that he necessarily did so" (85). So Barr, review of Jobes and Silva.

48 See HALOT I חָיזָ; H. Bauer and P. Leander, Historische Grammatik der hebräischen Sprache des Alten Testamentes (Halle: Max Niemeyer, 1922), §525i; David A. Robertson, Linguistic Evidence in Dating Early Hebrew Poetry, SBLDS 3 (Missoula, Mont.: Scholars Press, 1972), 76-77.

49 See Emanuel Tov, The Greek and Hebrew Bible, VTSup 72 (Leiden: Brill, 1999), 210-11.

50 Given the way human brains read written texts - recognizing whole words at a time — it is equally possible that the translator (or scribe) simply mistook חיות מיתו; Stanislas Dehaene, Reading in the Brain: The Science and Evolution of a Human Invention (New York: Viking, 2009), 222-25.

51 On scribes engaging in this sort of activity, see David Andrew Teeter, Scribal Laws, FAT 92 (Tübingen: Mohr Siebeck, 2014).

52 Cf. a similar phenomenon in OG Exodus, where plural ع̌ $\rho \gamma \alpha$ is often used for singular Screnock, Traductor Scriptor, 115. And cf. Margolis, "Identification of Vocabulary," 305, on the [nonJrepresentation of grammatical number with generic nouns. 
rendered as singulars, it would be much more probable that OG's plural in 104:11 stems from a variant Vorlage; but this is not the case. In Ps 104:11, then, we have a case where the OG did precisely the same thing with the text as a Hebrew scribe (evidenced in $4 \mathrm{QPs}{ }^{\mathrm{d}}$ ); the difficulty of the Hebrew, not the context of translational activity or transfer into Greek, is the driving force of the change.

Even in cases that look like textual corruption within the transmission of the OG, it is worth considering whether the change could have occurred in Hebrew. In Ps 104:10, for example, the OG has a small plus, reading $\delta 1 \varepsilon \lambda \varepsilon v ́ \sigma o v \tau \alpha \imath$ v $\delta \alpha \tau \alpha$, "waters will pass

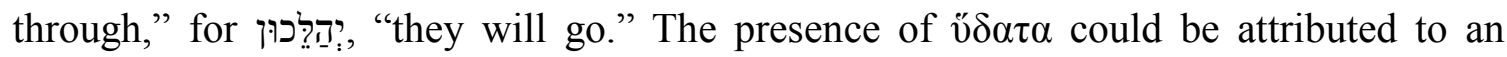
ocular skip in Greek to verse 6, which ends similarly: $\sigma \tau \eta \dot{\sigma o v} \tau \alpha \iota$ v̋ $\delta \alpha \tau$. A transmitter of OG Psalms may have turned his eye to the incorrect position given the identical string of

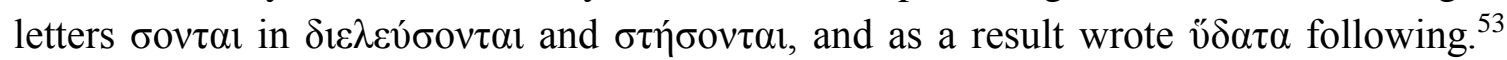
On this explanation, we would eliminate the OG evidence as not applicable for $\mathrm{HB}$ textual criticism. But could the same process have occurred with a scribe working in

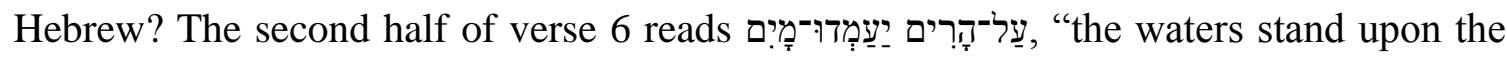

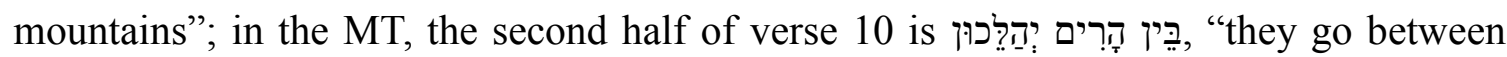
the mountains," with the subject, מַעִיָנינים ("springs") gapped from the preceding clause. If

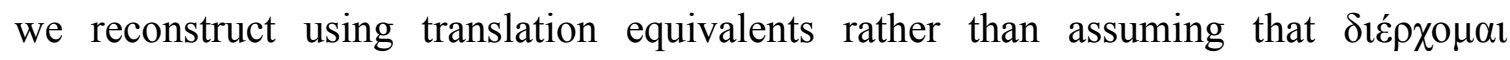
בין הרים הלך translates the MT's Piel, the Hebrew behind the OG in verse 10 is plausibly יעברו מים (see below). Given the similar contexts and meaning of the two clauses, and

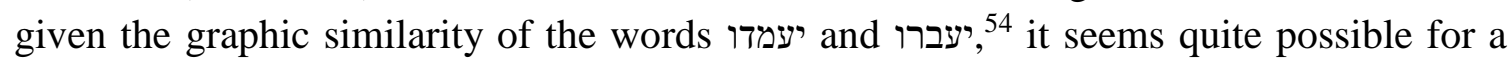

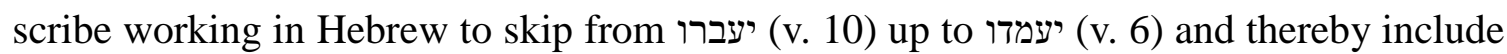
the plus מים ${ }^{55}$ Which explanation bears the burden of proof: inner-Greek textual

53 An inner-OG scribal error is perhaps the view of Albert Pietersma reflected in the translation "they will flow" in NETS, with a footnote indicating that Rahlfs' text includes "waters." In fact, there is very little textual support for the minus, all of which is likely the result of recension to the proto-MT Hebrew.

54 For an ocular skip between lines to occur as I am suggesting, it is crucial that entire words-not just their endings or beginnings - are similar; Jonathan Vroom, "A Cognitive Approach to Copying Errors: Haplography and Textual Transmission of the Hebrew Bible," JSOT 40 (2016): 259-79.

55 Hossfeld and Zenger suggest another possibility, that this is a purposeful insertion that "establishes a parallel to v. $6 \mathrm{~b}$ : The waters that stood threateningly on the mountains ... are now the waters that satisfy the thirst of the animals"; Frank-Lothar Hossfeld and Erich Zenger, Psalms 3: A Commentary on Psalms 101-150, Hermeneia (Minneapolis: Fortress Press, 2011), 59. Whereas Bons et al. think

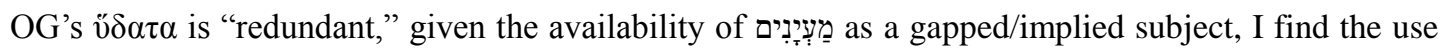

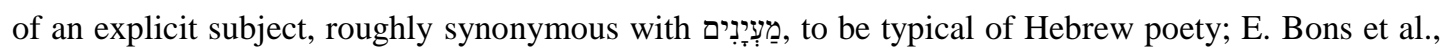
"Psalmoi: Das Buch der Psalmen," in Septuaginta Deutsch: Erläuterungen und Kommentare II, Psalmen bis Daniel, eds. Martin Karrer and Wolfgang Kraus (Deutsche Bibelgesellschaft, 2011), 1792. Rolf Jacobson considers the OG to reflect the plus מים, but quickly dismisses it as "unnecessary and unlikely"; Nancy DeClaissé-Walford, Rolf A. Jacobson, and Beth Laneel Tanner, The Book of Psalms, NICOT (Grand Rapids, MI: Eerdmans, 2014), 771. Hossfeld and Zenger's explanation may be correct, or such literary and theological considerations may have played a role alongside an ocular 
corruption because of a skip from $\delta \varepsilon \lambda \varepsilon v ́ \sigma o v \tau \alpha \iota$ to $\sigma \tau \eta ́ \sigma o v \tau \alpha \iota$, or a textual corruption in transmission of the Hebrew because of a skip from יעמדו to I suggest that we should assume the latter unless the former can be proven conclusively.

In summary, for any kind of inner-translational factors in Tov's methodology, we should consider whether the change could have occurred at the hands of scribes, and potentially shift the burden of proof onto explanations that see translation as a more likely catalyst for change than transmission. ${ }^{56}$

\subsection{Extending Mental Variants to All Types of Change}

Another way in which I develop Tov's methodology is an extension of his concept that variations can occur in the translator's mind. As discussed above, Tov makes much use of the idea when applied to scribal error. I see no reason, however, not to apply the same principle to other types of OG divergence, and contextual exegesis in particular. If we return to the example cited above from Gen 9:22, it is clear that the Greek of the OG isomorphically represents Hebrew.

Figure 2 - Genesis 9:22

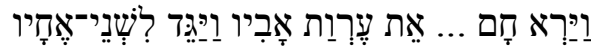

And Ham saw ... the nakedness of his father, and he made it known to his two brothers.

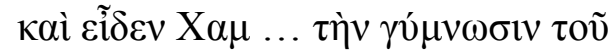

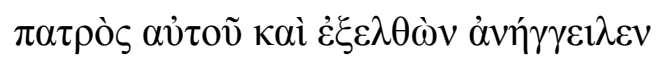

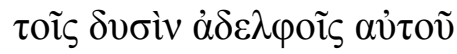
And Cham ... saw the nakedness of his father, and after he had gone out he told his two brothers. (NETS)

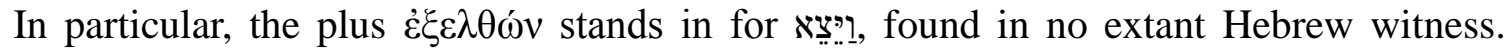
Beside the possibility that the OG's Hebrew Vorlage contained וּי., discussed above, we

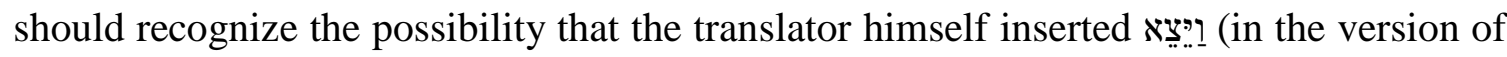
the text held in his mind) and then translated it into Greek. Whether one or the other is the case in this particular instance, I do no know; however, I am certain that at least some of the OG's isomorphic pluses came about in this manner, just as some of the scribal errors reflected in the OG stem from the translator, as recognized by Tov. ${ }^{57}$ We could,

skip; regardless, the same manner of change could have been introduced equally by the OG translator or by a scribe working with Hebrew.

56 So Melvin Peters, "Translating a Translation: Some Final Reflections on the Production of the New English Translation of Greek Deuteronomy," in "Translation is Required": The Septuagint in Retrospect and Prospect, ed. Robert Hiebert, SBLSCS 56 (Atlanta: Society of Biblical Literature, 2010), 121-34; and Sarianna Metso and Eugene Ulrich, "The Old Greek Translation of Leviticus," in The Book of Leviticus: Composition and Reception, eds. Rolf Rendtorff and Robert A. Kugler, VTSup 93 (Leiden: Brill, 2003), 253.

57 After presenting parts of this paper at a conference, I was asked during the Q\&A how I knew that my examples stem from the Hebrew text in the translator's mind, rather than the Vorlage. I responded that 
then, imagine three basic scenarios for how the difference between the MT and OG came about. First, the OG's Vorlage may have differed from the MT, reading ויצא ויגד) Second, the OG's Vorlage may have contained the same text as the MT (ויגד), but the translator while processing the Hebrew in his mind ${ }^{58}$ arrived at the Hebrew

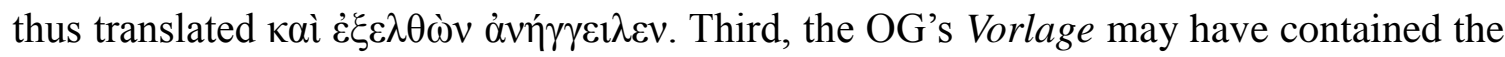
same text as the MT, the translator may have read it as such, and then after working out a

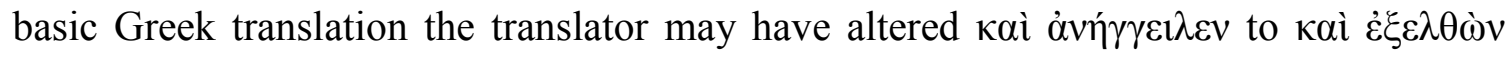
$\dot{\alpha} v \eta ́ \gamma \gamma \varepsilon 1 \lambda \varepsilon v$.

I have argued at length for the view that the OG translator had a "mental text," an intermediate stage in Hebrew between the Vorlage and the Greek translation, where changes could be made by the translator in Hebrew. ${ }^{60}$ Based on internal data in the OG, the science of reading and cognition, and other known translational phenomena-for example, pseudo-translation - the notion of a mental version of the Hebrew text is indisputable. The mental construction of the Hebrew text in the translator's mind would have been active at all points of translation and would have touched all aspects of the Hebrew text. Its activity was not confined to scribal errors. However, Tov's methodology excludes translator-induced content change before moving to the process of retroversion and focuses on scribal error as the sole area where translator induced change could occur in Hebrew. In fact, content related changes - and some linguistic changes - made by the translator could easily have been made in Hebrew to the translator's mental version of the Hebrew text. The ramifications are, first, that we should start with retroversion based on translation evidence before considering whether the change has to do with contextual or linguistic evidence; and second, that we should be just as unsure about cases of contextual and linguistic evidence as we are about scribal errors: a retrovertable variant could equally stem from the translator or from a scribe copying in Hebrew. ${ }^{61}$

Lest the reader think I am selectively choosing from Tov's examples and flattening his method, I would point out that the sorts of changes detailed in his section on contextual exegesis can be conceived of as changes made by scribes, and many actually occur in Hebrew manuscripts. To cite another example, Tov understands OG Exod 32:26

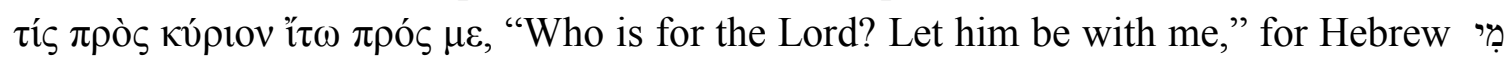
, לַיהוזה אֵּרי ,Who is for the LORD? [Let him come] to me," to be contextual exegesis, and

there are hundreds of isomorphic pluses in the OG, and at least some of these must stem from the translator. My interlocutor insisted that this should not be assumed, seeming to suggest the possibility that all of these differences stem from variant Hebrew texts which the OG simply followed, but I remain unconvinced. While it is remotely possible that all of our OG isomorphic pluses stem from a variant Vorlage, it is highly probably that at least some came about at the instigation of the translator.

58 The same "chunk" of text would have been processed multiple times at various points; cf. Screnock, Traductor Scriptor, 85-86.

59 I vocalize the text because the virtual mental text of the translator would have been phonological.

60 Screnock, Traductor Scriptor, 72-92.

61 It is worth reiterating that a third possibility is available: the OG reading stems from a Hebrew reading that is earlier than the variant reading in other witnesses. 
therefore eliminated from the process before the step of retroversion. ${ }^{62}$ But we could argue that í

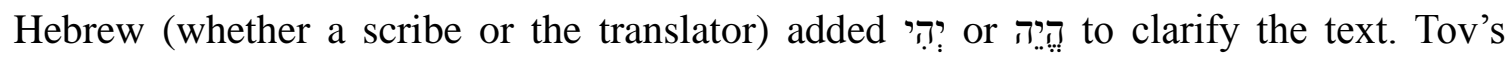
examples of omission ${ }^{63}$ could have occurred within transmission of the text in Hebrewno Greek is necessary for this kind of change. If one counter-argued that the additions and omissions are demonstrably a feature of translation applied systematically in the $\mathrm{OG},{ }^{64}$ then we are not dealing with contextual exegesis, since our translational evidence clearly points us to a reconstruction that agrees with the Hebrew. Many of Tov's examples come from OG books where the translator is known to take a certain approach to the Hebrew text - the OG of Isaiah, ${ }^{65}$ for example - where it is hard to dispute that the translator made a change similar to similar changes made elsewhere. To take one

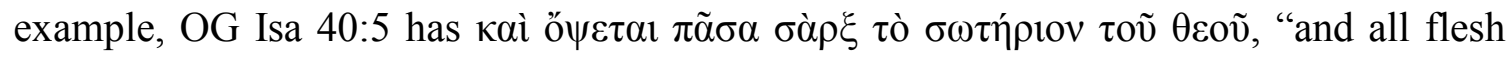
shall see the salvation of God," for Hebrew וראו כל בשר יחדו, "and all flesh shall see together"; Tov argues that the translator made the change because OG Isaiah is prone to add the terminology/concept of $\sigma \omega \tau$ ípıov, "salvation." "66 However, we could argue that

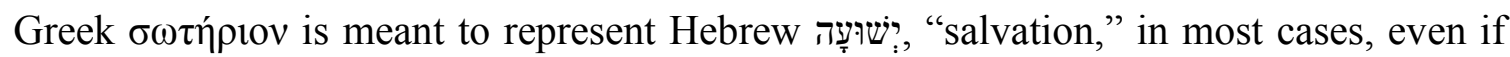
the translator is responsible for the addition; and moreover it is not implausible to think of a scribe adding reference to a concept like ישוּעָה throughout a Hebrew text. ${ }^{67}$ Even if the translator made the change in Isa 40:5 as argued by Tov, the sorts of changes made in Tov's examples are not unique to translation.

Translators changed the text in the same ways and for the same reasons as scribes, and they very often did so in Hebrew. As Tov states regarding scribal errors, "even if a retroverted variant bears all the marks of a well-supported reading, such a reading may never have existed anywhere but in the translator's mind," and "it can never be known whether the error was made by the translator or was already present in his Vorlage." 68

62 Tov, Text-critical Use of the Septuagint, 51.

63 Tov, Text-critical Use of the Septuagint, 52-53.

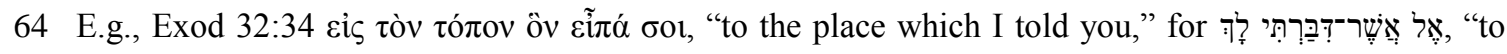
[the place] concerning which I spoke to you," may simply stem from translation technique; Tov, Textcritical Use of the Septuagint, 51. Compare the English "to the place of which I have spoken to you" (RSV), which hardly engages in contextual exegesis; rather, for linguistic reasons the English needs to clarify the null constituent that is assumed in the Hebrew.

65 Goshen-Gottstein's "Theory and Practice" also uses evidence from OG Isaiah extensively as a basis for his theory.

66 Tov, Text-critical Use of the Septuagint, 53-54.

67 Indeed, Eugene Ulrich strongly questions attribution to the OG translator in Isa 40:5, attributing the reading instead to the OG's Vorlage: "salvation" and related themes are already important features of the Hebrew text, and moreover Isa 52:10 in both Hebrew witnesses and the OG contains a statement

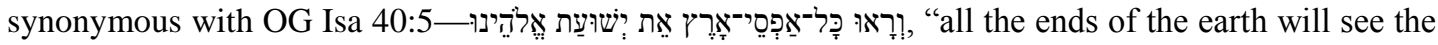

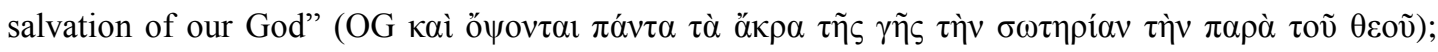
Eugene Ulrich, personal correspondence.

68 Tov, Text-critical Use of the Septuagint, quoted from 98 and 178, respectively; emphasis original. 
While not always applicable to other types of variation found in the OG, in most cases we can extend this sentiment to Tov's categories of linguistic and contextual exegesis as well: it can never be known whether a variant (scribal error, linguistic exegesis, contextual exegesis, and earlier readings) was made by the translator or was already present in his Vorlage.

\section{A New Approach to the Old Greek}

Rather than focusing on the potential for the translator to make change, I suggest we focus on reconstruction of the possible Hebrew readings behind the Greek. In the approach I will articulate below ( $\S 3.1-5)$, the primary reason for disqualifying the OG as evidence in HB textual criticism is that we cannot reconstruct its Vorlage with much certainty or that the reconstructed Vorlage is not grammatical Hebrew. I postpone considerations of contextual exegesis, scribal error, and the like until after I have a Hebrew Vorlage in mind, and as such I do not slant the questions we ask toward disqualification of OG evidence. ${ }^{69}$ To use Tov's example of Gen 9:22 discussed above, the question Why does the OG reflect the Hebrew Iיֵי question Why does the OG contain $\dot{\varepsilon} \xi \varepsilon \lambda \theta \omega \dot{v}$. This reordering of priorities reflects the methodological points I argue in section 2, namely, that we ought to assume change in Hebrew unless evidence tells us otherwise, and that we ought to use the concept of Hebrew variants in the translator's mind more broadly.

Another distinctive of my approach is a heightened stress on translation evidence to constrain retroversion of the Hebrew source. While it is broadly recognized that we should not reconstruct without first understanding the translation technique of the OG, I emphasize statistical significance and probability as essential criteria. We cannot retrovert with confidence unless there is ample translation data (more than a handful of cases) and the translation equivalence on which the retroversion is based occurs in a clear majority of cases. Moreover, I nuance the role of external text-critical considerations in the retroversion of Hebrew differently: whereas Tov and others would have us base our retroversions on fit with the other text critical data, I argue that such fit can only play a supporting role. The retroversion must have a good probability from the standpoint of translation evidence alone, though external evidence can strengthen the probability.

Whereas Tov does not take issue with retroversions that use uncommon translational equivalences, and allows for reliance on scholarly intuition, I argue that we should rely almost entirely on translational evidence, and we should not allow ourselves

69 Compare, for example, James Barr's summative statement in Comparative Philology, 245: "Where the Greek text gives a sense different from the Hebrew, the hypothesis that it was translated from a different Hebrew text is only one of a number of possibilities. It may have had the same text, but misread it; or been careless in handling it, or guessed at the sense, or paraphrased, or assimilated it to another passage[.] [...] Only when we eliminate a number of these possible relations are we entitled to translate back the Greek into a Hebrew text and say that the translators 'read' this text." 
to venture beyond well-established translation patterns. ${ }^{70}$ For this reason, the approach that I propose works best, and is safely applied only, with more-or-less isomorphic OG translations: for example, the books of the Pentateuch, Joshua-2 Kings, Psalms, and Ecclesiastes. ${ }^{71}$ It is in such translations that we have access to enough data for reconstruction, and where we can expect the translational processes from elsewhere to be followed in the particular case in view. ${ }^{72}$ Text-critics of books in the Hebrew Bible where the OG translation is not isomorphic must appeal to other methods-including perhaps the use of scholarly intuition.

My approach can be summarized as follows: if grammatical Hebrew can be reconstructed from the $\mathrm{OG}$ on the grounds of clear isomorphic translation patterns, then we typically should use the reconstructed Hebrew in HB textual criticism, ignoring the potential for translator exegesis and scribal error. ${ }^{73}$ There are some caveats to this simple expression of my approach, but they are exceptions rather than the norm. In what follows, I articulate an approach to the OG that takes seriously our inability to distinguish inner-translational data from data reflecting a Hebrew Vorlage, as well as the necessity for robust translation evidence in order to retrovert Hebrew. While most pieces of this approach are not new, I am not aware of any published methodology that have put them together in the same way; moreover, I propose new points of emphasis and priority.

\subsection{Awareness of OG Text-critical Data}

At the outset, we should of course be aware that the manuscripts of the OG do not always agree on readings, and therefore we should work with a critical text when available and consider variant readings in OG manuscripts. ${ }^{74}$ This ensures that we are comparing the OG translation at the point of its production (which is where the OG intersects most with the HB textual tradition) rather than a later development of the OG text in its reception. ${ }^{75}$ If we have a critical text, it is still worth considering variant

70 Cf. Aejmelaeus, On the Trail, 74.

71 See the introductions to these books in Albert Pietersma and Benjamin G. Wright, eds., A New English Translation of the Septuagint (New York: Oxford University Press, 2007); though some scholars have characterized some of these books as "free" translation, it is my opinion that the existence of some target-oriented translation does not outweigh the overwhelming isomorphic character of these translations; cf. my discussion of Exodus, against Aejmelaeus and Lemmelijn, in Traductor Scriptor, $43-44$.

72 Cf. Aejmelaeus, On the Trail, 78.

73 Cf. Screnock, Traductor Scriptor, 44.

74 Barr, Comparative Philology, 247-48; Wevers, "The Use of the Versions," 19-20; Aejmelaeus, On the Trail, 72, 74-75; Tov, Textual Criticism, 122; Tov, Text-Critical Use of the Septuagint, 44, 49, 55-60, 88-89. Peter Gentry emphasizes the importance of therefore "[basing] our research and study upon critical editions of the text of the Septuagint"- though he does not himself heed this principle, citing examples elsewhere from recensions of the OG; Gentry, "The Septuagint and the Text of the Old Testament," 195-96, 198, 202, quoted text from 196.

75 See the important distinction of production and reception in Pietersma, "Messianism and the Greek 
readings, insofar as the critical text may be wrong. ${ }^{76}$ Even if we do not deem a variant reading to be the original OG, secondary readings may sometimes have come about by reference to early Hebrew manuscripts. The evidence shows clearly that some manuscript traditions corrected the text of Exodus, for example, to a proto-MT Exodus text. Scribes of the OG, then, were consulting Hebrew manuscripts when they copied the Greek, and whether the manuscripts were proto-MT or not, they would have contained variants compared to the MT. In Ps 104:5, for example, the earliest OG reading for the initial word is $\dot{\varepsilon} \theta \varepsilon \mu \varepsilon \lambda i i^{\prime} \omega \sigma \varepsilon$, "he founded," an aorist indicative verb reflecting Hebrew (as in the MT). A number of good OG witnesses, however, have the participle o $\theta \varepsilon \mu \varepsilon \lambda i \omega v$, "the founder," reflecting Hebrew יo (as in 4QPs ${ }^{\mathrm{d}}$ ). ${ }^{77}$ While it is possible that the variant arose from inner-Greek phenomena only_perhaps the string of participles in vv. 2-4 induced another participle here for literary reasons - the correspondence with other early witnesses ${ }^{78}$ tips the balance in favor of viewing o $\theta \varepsilon \mu \varepsilon \lambda i i_{\omega}$ v as a Hebrew induced reading. ${ }^{79}$ When two (or more) OG readings plausibly stem from Hebrew

Psalter," 50-52.

76 Rahlfs, for example, had a penchant for prefering readings that agree with the MT; cf. Albert Pietersma, "The Present State of the Critical Text of the Greek Psalter," in Der Septuaginta-Psalter und seine Tochterübersetzungen: Symposium in Göttingen 1997, ed. Anneli Aejmelaeus and Udo Quast, Abhandlungen der Akademie der Wissenschaften zu Göttingen 230 (Göttingen: Vandenhoeck \& Ruprecht, 2000), 23. Taking a more recent example, Wevers was more judicious in how the MT influenced his text-critical decisions. In his critical text of OG Leviticus, he often prefers readings found in a minority of manuscripts that disagree with the MT (e.g., in Lev 5:2, 4; 6:5, 15; 9:7, 8, 11, 21). However, elsewhere he appears to prefer a minority reading because it agrees with the MT; for example, in Exod 1:12 he claims that "the majority text [+ $\left.\sigma \varphi o ́ \delta \rho \alpha \sigma \varphi \delta^{\delta} \rho \alpha\right]$ can hardly be original LXX; it has no basis in the parent text nor does it correctly interpret it"; John William Wevers, Text History of the Greek Exodus, MSU 21 (Göttingen: Vandenhoeck \& Ruprecht, 1992), 239. In fact, the reading preferred by Wevers by virtue of agreeing with the "parent text" (= MT for Wevers!) is found in manuscripts that elsewhere correct OG to a proto-MT text (F $426 s^{-321 \mathrm{mg}} 121$ ' 59509 Aeth Bo Syh).

77 Lucianic witnesses, A, 1219, and 55 have o $\theta \varepsilon \mu \varepsilon \lambda i \omega v$, as well as the Boharic translation (which usually agrees with B and $\mathrm{S}$, but is known to follow the Lucianic recension at times); B, S, R, and 2044 have $\dot{\varepsilon} \theta \varepsilon \mu \varepsilon \lambda i ́ \omega \sigma \varepsilon v$.

78 Namely, 4QPs ${ }^{\mathrm{d}}$ and Jerome's Hebrew-based Psalter (Hier); Hier usually amends the Latin of the Vulgate to agree with a proto-MT reading, but here retains qui fundasti (itself a translation of the Lucianic reading o $\theta \varepsilon \mu \varepsilon \lambda i(\omega v)$, most likely because the Hebrew text that served as the basis for recension in Hier had a participle here.

79 Given its agreement with 4QPs ${ }^{\mathrm{d}}$, scholars are open to the inclusion of this secondary OG evidence; cf., e.g., Leslie C. Allen, Psalms 101-50, revised, WBC 21 (Nashville: Thomas Nelson, 2002), 37. Whether or not there is corroborating Hebrew evidence, however, we should be willing to consider whether secondary OG readings stem from a Hebrew source. Others prefer the participle, but make no reference to the $\mathrm{OG}$ evidence, perhaps because it is secondary or because the scholar is unaware of the reading; e.g., Hans-Joachim Kraus, Psalms 60-150, Continental Commentary (Minneapolis: Fortress, 1989), 297; Nancy L. deClaissé-Walford, Rolf A. Jacobson, Beth LaNeel Tanner, The Book of Psalms, NICOT (Grand Rapids, MI: Eerdmans, 2014), 771; Mitchell Dahood, Psalms III, AB 16 (New York: 
manuscripts, the following steps should be followed for both OG readings.

\subsection{Establishing Translation Patterns and Reconstructing Hebrew on that Basis}

The most important step in my approach is to establish potential translation patterns that guide retroversion into Hebrew. ${ }^{80}$ First and foremost, it is crucial that we have a good understanding of the Greek and Hebrew languages and what is grammatically possible within each. The myriad of differences between these is the primary fact of translation and translation analysis. ${ }^{81}$ Second, one must have a good grasp of the general translation character of the OG book in question. ${ }^{82}$ Third, as Tov notes, retroversions should stem from "vocabulary equivalences between the $[\mathrm{OG}]$ and MT which are found elsewhere in the [OG]"; we should add that grammatical equivalences are equally important. ${ }^{83}$ In some fortunate instances, published studies of particular lexemes or grammatical phenomena are very helpful in establishing translation patterns, but we cannot count on others to have fully researched the data on every particular issue encountered in the texts. Vocabulary equivalences can be established using the Hatch-Redpath concordance, ${ }^{84}$

Doubleday, 1995), 35.

80 For an earlier statement of some of these points, see Screnock, Traductor Scriptor, 105-106.

81 Cf. Wevers, "The Use of the Versions," 15-19; Notes on the Greek Text of Exodus, SBLSCS 30 (Atlanta: Scholars Press, 1990), vii; Aejmelaeus, On the Trail, 76. Even the most isomorphic translations cannot carry over every grammatical element of the source text because of differences between the two languages. There are always competing possibilities: a translation can represent one aspect of the language, but to do so it must ignore another. To take a simple example, the grammatical number of Greek nouns often represents that of their Hebrew counterparts, but not always: when a collective Hebrew noun is paired with a non-collective Greek noun, we often find Greek plurals for

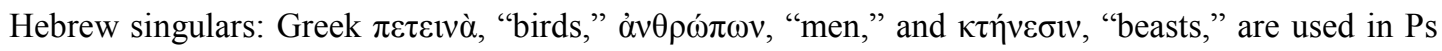

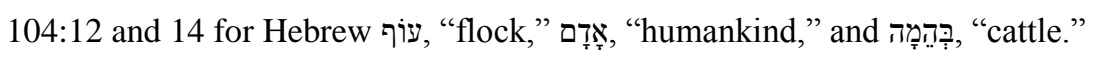

82 Tov, Text-Critical Use of the Septuagint, 18, 48-49; Wevers, "The Use of the Versions," 20-24; Aejmelaeus, On the Trail, 72-73; Barr, Comparative Philology, 250-59; Lemmelijn, A Plague of Texts?, 19, 23-24, 103-104; Margolis, "Identification of Vocabulary," 302-303. Understanding a book's translation technique includes attention to contextual contraints on individual renderings and attention to the ways in which translation technique may have developed during the course of translation; see Theo van der Louw, "The Evolution of the LXX-Genesis Translator," in Die Septuaginta: Geschichte - Wirkung - Relevanz (Tübingen: Mohr Siebeck, 2018), 146-57. For an illustration of the point, see W. Edward Glenny's critique of Anthony Gelston in “Hebrew Misreadings or Free Translation in the Septuagint of Amos?," VT 57 (2007): 524-47; Glenny demonstrates that most of the cases Gelston describes as scribal error could easily be described instead as typical translation practice in OG Amos. For examples of non-variants in OG Exodus that are best explained as results of translation technique, see Screnock, Traductor Scriptor, 111-116.

83 Cf. Margolis, "Identification of Vocabulary," 304, 311-12, and throughout.

84 Edwin Hatch and Henry A. Redpath, A Concordance to the Septuagint and the Other Greek Versions of the Old Testament (Including the Apocryphal Books), 2d ed. (Grand Rapids, Mich.: Baker Books, 1998). 
reverse engineered versions of Hatch-Redpath, ${ }^{85}$ the CATSS database, ${ }^{86}$ and Bible software. Grammatical equivalences can be established using the CATSS database and Bible software. ${ }^{87}$ I would emphasize that such research must be set in the context of the general translation profile of the OG book in question, because the data derived from these sources may not take into account other aspects of translation technique. ${ }^{88}$ When researching a translation issue using any of these resources, we should keep in mind the particular nature of individual OG books, which in specific matters of translation may differ from other OG books; rather than assuming that our OG text will follow the same translation patterns of other OG texts, we should focus on translation data from within the particular OG text itself. ${ }^{89}$ Of course, translation techniques were somewhat unified across the different texts of the $\mathrm{OG},{ }^{90}$ and the Pentateuch, in particular, was looked to as a model for lexical choices.

Fourth, it is important that we not think only in terms of what the Greek most likely represents, but also how various hypothetical Hebrew readings would likely be translated into Greek. In Ps 104:8, for example, the OG has $\pi \varepsilon \delta i ́ \alpha$, "plains," for Hebrew בְקָעוֹ

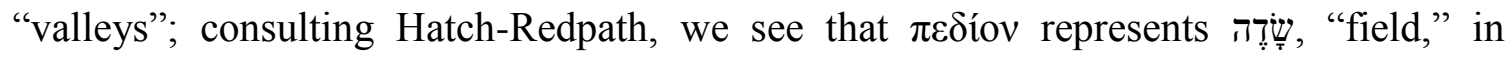

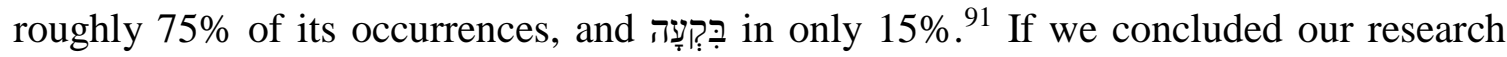
here, we might incorrectly think that שָָָָָׁה in is represented by the Greek here. When we add

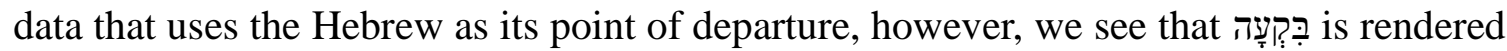

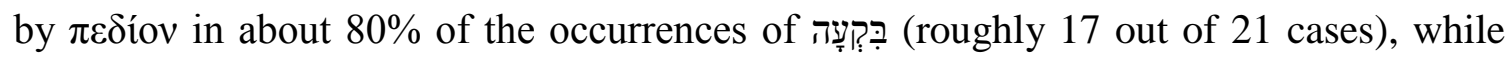
i⿱宀⿻⺀大 is rendered $\pi \varepsilon \delta$ íov about $25 \%$ of the time (roughly 84 out of 321 cases). The high

85 Elmar Camilo dos Santos, An Expanded Hebrew Index for the Hatch-Redpath Concordance to the Septuagint (Jerusalem: Dugith Publishers, 1973); Takamitsu Muraoka, "Hebrew/Aramaic Index to the Septuagint," in Hatch and Redpath, A Concordance to the Septuagint. I prefer the former resource, insofar as it lists word counts rather than simply noting an equivalence (whether it appears once or 300 times); dos Santos's word counts are not always perfectly accurate, but they quickly give a general idea of how the evidence patterns.

86 Emanuel Tov and Frank Polak, The Revised CATSS Hebrew/Greek Parallel Text (Jerusalem, 2009).

87 The use of such tools is always limited, however, by the ability of search-terms to represent the feature in question, and moreover by the scholar's conception of what complexities might be involved. Computers are no substitute for depth of knowledge and experience in reading the Greek text alongside the Hebrew. Nevertheless, computer software presents a significant advantage compared to previous generations of scholars; cf. Margolis's method of "complete induction" in the age before computers in "Identification of Vocabulary," 310-12.

88 For example, there may be contextual and semantic peculiarities informing whether one equivalent is chosen versus another. I employ many examples here that follow the bare data because OG Psalms largely works in this manner-lexical isomorphism across one corpus, with limited regard to contextual issues — and indeed, many OG books generally follow the same translation technique.

89 Cf. Margolis, "Identification of Vocabulary," 306.

90 So Margolis, "Identification of Vocabulary," 304, who argues that we should begin with the shared translation techniques of all the translators before distinguishing "idiosyncracies of the individual translators."

91 Hatch-Redpath $\pi \varepsilon \delta$ íov. 
percentage of cases where $\pi \varepsilon \delta$ íov maps to שָָָׁדה

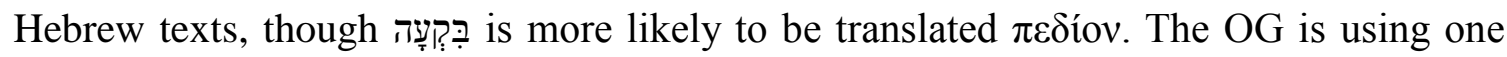
Greek word for several Hebrew words (semantic leveling). Note that isomorphic translation does not entail very simple one-to-one correspondence between linguistic items only; it often involves more complex relationships, with several overlapping oneto-two (or three) and two-to-one relationships between Hebrew and Greek words and structure. Considering all the data and the basic isomorphic framework OG Psalms,

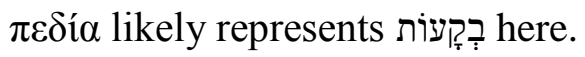

In order to be data driven, rather than relying on scholarly intuition, it is key that we have concepts of statistical significance and thresholds for probability. These two concepts have never, to my knowledge, been applied explicitly in methodological discussions of the OG's role in HB textual criticism. ${ }^{92}$ How often does a Greek lexeme (or grammatical structure) need to represent a Hebrew lexeme (or grammatical structure) in order for us to consider it likely that it represents that same Hebrew in the case in view? The question involves both the amount of available tokens necessary (statistical significance) and the proportion of those tokens that pattern together (resulting in probability that other cases pattern similarly). Ps 104:10 presents an example where, in my opinion, the translation data is on the borderline in terms of probability. OG's $\delta 1 \varepsilon \lambda \varepsilon v ́ \sigma o v \tau \alpha$, "they pass through," is very improbable for Hebrew [?] יהלכו', "they go [about]," (as in 4QPs ${ }^{d}$ and the MT). Outside of the possible case of Ps 104:10, there is only one case of $\delta 1 \varepsilon \rho \chi 0 \mu \alpha$ for Piel הלך in the OG, in Lam 5:18, and הלך in other stems is not often translated with $\delta 1 \varepsilon \rho \chi o \mu \alpha 1$; other Hebrew lexemes-most notably עבר -are more likely to stand behind OG's $\delta \varepsilon \rho \chi 0 \mu \alpha 1 .{ }^{93}$ In terms of the probability of הלך עבר here, the evidence points clearly to a negative conclusion (not probable). But what would we

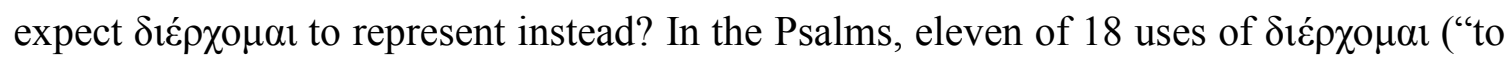
pass through") stand for Qal עבר ("to pass over/through"), while the the other seven

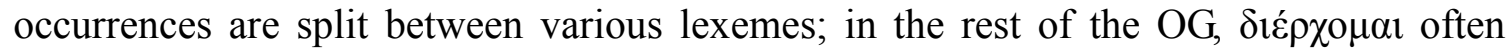
represents עבר as well. ${ }^{94}$ Note that the bare percentage usage (61\%) does not accurately reflect the entire situation: the fact that no other equivalence is used with regularity makes the $61 \%$ stronger. If the seven other occurrences all corresponded to a second

92 For example, in Tov, Text-critical Use of the Septuagint, 65-66, a lexical equivalence does not need to occur frequently to be a viable option for reconstruction; cf. my critique of the reconstruction of Hebrew יסד for OG's $\sigma \tau \eta \rho i \zeta \zeta \varepsilon 1$ in $\$ 3.3$.

$93 \Delta$ הל 9 הלך just twice in the Pentateuch, compared to עבר $\sqrt{ }$ עepresents eight times. In Josh-2 Kgs

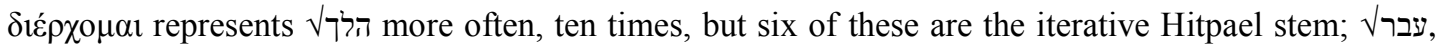

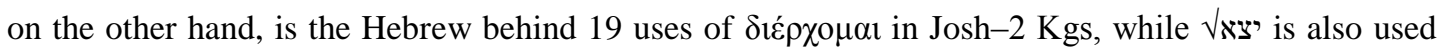
often in Joshua (seven times). When we focus on the Psalms, where the data is most relevant, 11 of 18

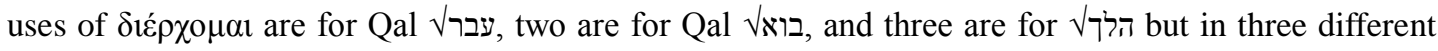
stems — once the Qal, once the Piel (here), and once the Hitpael. Note that the yiqtol verb is distinct in the Piel from the yiqtol Qal of הלך; the OG translator could not have read יהלכון as a Qal verb. HatchRedpath, $\delta i \varepsilon ́ \rho \chi \varepsilon \sigma \theta \alpha 1$.

94 See footnote above. 
Hebrew word, the $\delta 1 \varepsilon$ $\rho \chi 0 \mu \alpha 1-Q a l$ עבר pairing would be weaker. Working the other way around, if the Hebrew source text had Qal עבר, it is possible that the OG would have used

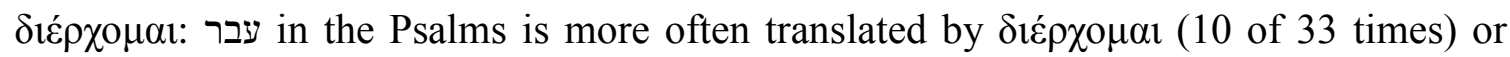

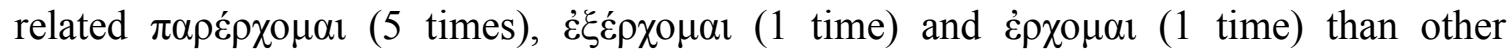
lexemes (16 remaining, none of which pattern together). Again, 17 out of 33 is only $51 \%$, but the likelihood increases because the other 16 occurrences are scattered between different lexemes. Do we have enough evidence to consider $\delta 1 \varepsilon \lambda \varepsilon v ́ \sigma o v \tau \alpha$ to represent יעברו here (statistical significance)? Yes; compared to cases where only a handful of tokens are available, this case has tens of tokens of evidence on which we can establish translation patterns. Is it likely that $\delta 1 \varepsilon \lambda \varepsilon v ́ \sigma o v \tau \alpha \iota$ represents יעברו (probability)? No, not based on translation evidence alone. Although the absence of other often-occurring pairings- $\delta 1 \varepsilon \rho \chi 0 \mu \alpha$ for Qal עבר is the only regularly used pairing-pushes us in the direction of using יעברו, I am much more comfortable retroverting the OG when the lexical pairings are closer to $80 \%$ in correspondence, and not lower than $70 \%$. In the end, non-translational evidence (specifically, consistency with possible text-critical development; see below) puts us into the realm of likelihood. But if we had only $60 \%$

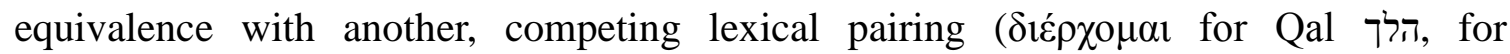
example), I think the data would be inconclusive.

Other cases in Ps 104 where we lack the necessary data for statistical significance or where the probability is on the borderline include v. 7, where the OG's $\delta \varepsilon \imath \lambda$ ió $\sigma 0 v \sigma v v$

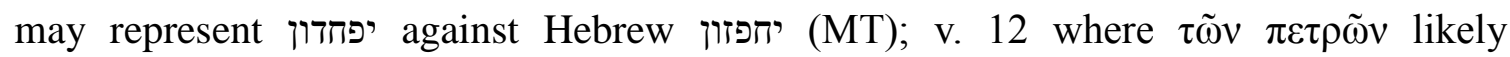
represents עפאים (MT) despite lacking translational data (text-critical evidence tips the balance toward אבנים being a probable reconstruction); 95 and v. 14

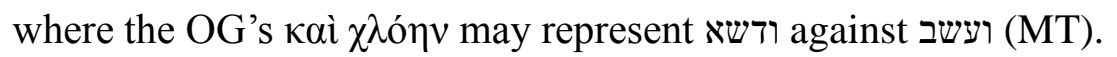

It is important to reiterate that this approach requires a generally isomorphic OG translation. The OG translation can certainly utilize free or target oriented techniques of translation at times, but the overarching translational framework must be source oriented and isomorphic. ${ }^{96}$

\subsection{OG Data Eliminated based on Translation Patterns and Reconstruction}

When the principles just articulated are followed, a fair amount of OG evidence must be dismissed as unusable. ${ }^{97}$ OG evidence is excluded if (1) there are no statistically significant and probable translation patterns on which to base Hebrew retroversion, (2) clear translation patterns entail that the OG could represent multiple Hebrew readings, or

(3) the retroverted Hebrew reading is ungrammatical.

95 Contra Hossfeld and Zenger, Psalms 3, 59: עפאים "was unfamiliar to the LXX and has been translated from the context."

96 See my discussion of OG Exodus as isomorphic despite some free elements, against Aejmelaeus and Lemmelijn; Screnock, Traductor Scriptor, 43-44.

97 For a similar line of argument framed using different points, with specific examples from OG Exodus, see Screnock, Traductor Scriptor, 110-20. 
First, if there are no clear translation patterns, or if no translation patterns hold sufficient statistical significance, we cannot use the OG to reconstruct Hebrew. While scholars agree generally that retroversions should be based on translation evidence, my definition of what exactly this entails differs insofar as statistical significance and thresholds for probability are essential components for valid reconstruction (see §3.2). In Ps 104:15, for example, CATSS suggests that OG's $\sigma \tau \eta \rho i \zeta \varepsilon 1$, "it sustains," reflects the Hebrew root יסד, "to establish," rather than support," as found in 4QPs and the MT. The suggestion has little basis in translation data; $\sigma \tau \eta \rho i \zeta \omega$ is used only once to represent יסד in the OG (Sir 3:9), whereas סעד, which has no single isomorphically paired Greek equivalent, is glossed by $\sigma \tau \eta \rho i ́ \zeta \omega$ as often as any other gloss. ${ }^{98} \Sigma \tau \eta \rho i ́ \zeta \omega$ is much more often used for סמך, but the odds of o being translated $\sigma \tau \eta \rho i ́\} \omega$ are not high

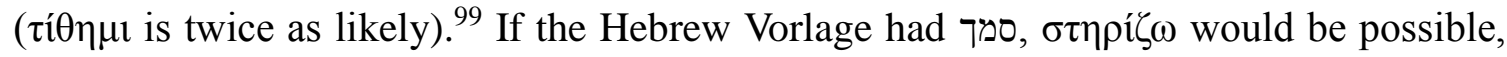

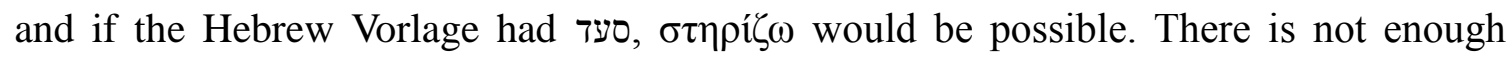
evidence to know with confidence what $\sigma \tau \eta \rho i ́ \zeta \omega$ represents.

One important caveat to the principle of statistical significance is that external support - data outside the realm of translation evidence - can tip the balance in favor of a particular retroversion. Specifically, manuscript readings and text-critical reconstruction provide evidence that must be considered. The idea here is similar to Tov's principle that retroversions should cohere with the development of the text evidenced in manuscript data. Though I would not include it as a main criterion for retroversion, coherence with text-critical evidence can provide additional support for a retroversion. In the example of Ps 104:10, discussed several times above, the translation evidence is not abundantly clear on the retroversion of OG's $\delta 1 \varepsilon \lambda \varepsilon v ́ \sigma o v \tau \alpha$. While it is clear is that $4 \mathrm{QPs}{ }^{\mathrm{d}}$ and the MT's reading [7] יהלכוי is not the Vorlage, we do not have enough evidence to confidently reconstruct Qal עבר until we consider also the possible text-critical explanations for OG's variation. An ocular skip to an earlier line was easily possible if a source manuscript was laid out according to the lines of the poem; a scribe transmitting the text in Hebrew (or

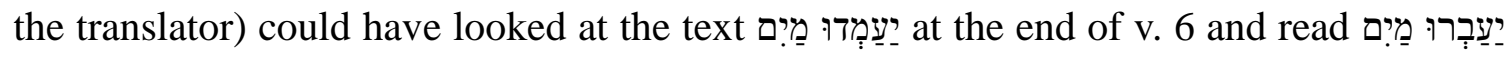
( $\delta \varepsilon \varepsilon \varepsilon \varepsilon v ́ \sigma o v \tau \alpha \imath$ v̋$\delta \alpha \tau \alpha$ ), a simple mistake induced by whole-word recognition in reading and the context of v. 10. The potential for such an error, coupled with the obvious plus

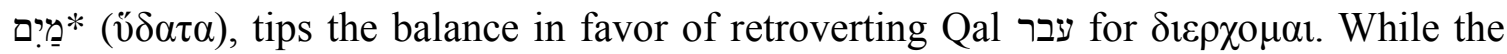
reconstruction of יסד, discussed above, is similarly based on external, text-critical considerations (the graphic similarity and synonymity of סעזד), there we have little translation evidence supporting the reconstruction-low probability-while here the probability of עבר is not clear-cut based on translation evidence alone, but neither is it low. The external evidence is not the basis of the retroversion, but it strengthens the case

98 Hatch-Redpath $\sigma \tau \eta \rho i \zeta \xi \varepsilon v$; Dos Santos derivation or exegesis" and presumably based in part on the the graphic similarity and synonymy of סעד ; given the lack of translation evidence to connect $\sigma \tau \eta \rho i \zeta \omega$ and is barely tethered to the OG and thus highly conjectural.

99 Dos Santos 
based on translation evidence.

Second, there are cases where translation patterns give a basic sense of what Hebrew lies behind the OG, but there are two equally plausible options. Semantic leveling - consistent representation of two or three Hebrew lexical items by one Greek item - presents many such cases. ${ }^{100}$

Third, after we have reconstructed Hebrew on the basis of established translation patterns, we must ask whether the reconstructed Hebrew is grammatical. ${ }^{101}$ If it is ungrammatical, it is unlikely to have been a Hebrew reading. One exception is if there is a clear scribal mistake, since Hebrew manuscripts also, when corrupted by scribal errors, can contain ungrammatical Hebrew. In a similar vein, if the Hebrew is highly unlikely in a Hebrew cultural context but fits well within a Hellenistic or Egyptian context, it is unlikely to have been a Hebrew reading. In Exod 1:11, for example, the plus $\ddot{\eta} \dot{\varepsilon} \sigma \tau \imath$

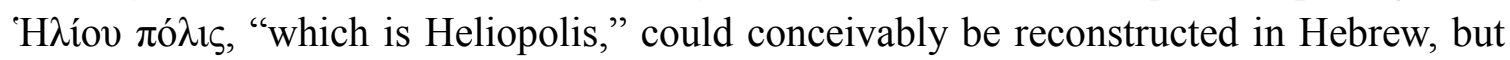
seems clearly to fit a Hellenistic context in Egypt, and as such the gloss was very likely added by the translator on the Greek level.

\subsection{Miscellaneous Disqualifiers}

Before taking our reconstructed Hebrew text to the task of textual criticism, a few final factors should be considered. If there are a high number of differences that pattern together in the OG, the probability that these derive from translation rather than the OG's Vorlage rises considerably - even if they all can be retroverted into Hebrew on the basis of established translation technique. I refer to phenomena like the use in OG Exod 1 of

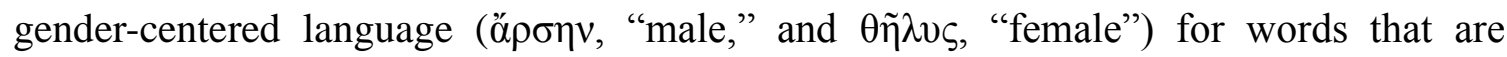

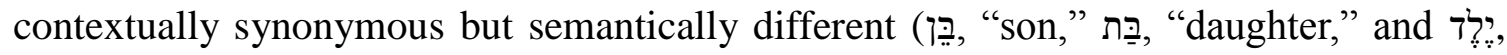
“youth") frequently within a brief passage. ${ }^{102}$ Although scribes were capable of making similarly widespread changes to a text, we need to think carefully about whether this particular type of widespread variation is evidenced in any Hebrew material (whether manuscript or rewriting) and whether it was possible or likely outside of a translation context. In cases like these, the balance of probability remains with explanations that place the variation with the translator rather than his underlying Vorlage. Arguments could still be made for such changes having occurred in the course of Hebrew transmission resulting in the OG's Vorlage. Moreover, when we imagine-as we should - whether and how such patterned variants may have arisen at the hands of scribes, we should not think only in terms of "single-dimensional revision" (fitting well with changes that occur at the point of translation), but also "incremental revision." 103

$100 \mathrm{Cf}$. the example of $\pi \varepsilon \delta$ íov in section 3.2 above.

101 Cf. Screnock, Traductor Scriptor, 107.

102 See Screnock, Traductor Scriptor, 119-20.

103 I follow here Justus Ghormley's typology: "single-dimensional revision" is "revision of one aspect of a text in a single moment by one scribe" or, in my discussion, translator; and "incremental revision" is "ongoing, piecemeal revision of one aspect of a text by an unknown number of scribes over a long 
And finally, we must keep in mind the third option: that the reading evidenced in the OG is earliest and therefore the differences found in the OG stem neither from change in translation nor change in transmission of the OG's Vorlage and its predecessors; in the case of gender-centered language in Exod 1, for example, it is worth considering whether

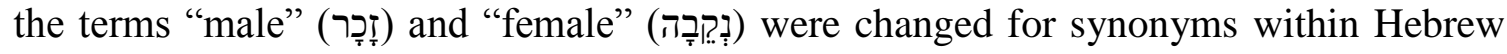
transmission - though in the end this is not the correct analysis in this particular case.

Another set of disqualifiers revolves around strategies for overcoming unintelligibility. In cases where the Hebrew text was not comprehendible to the translator for whatever reason, he had to interact with the linguistic information encoded in the written text and produce a Greek text to represent it, while a scribe who did not comprehend the Hebrew could resort to rote copying to avoid the difficulty. ${ }^{104}$ Various ways in which the OG reflects misunderstandings of the Hebrew text have been discussed at length elsewhere. ${ }^{105}$ Though a number of possible scenarios fall within this general category, it remains a less preferable explanation if there are alternatives, and it should not be appealed to without clear evidence.

Issues involving the impact of vernacular Hebrew and Aramaic on the translators often fall within the category of unintelligibility: if an OG translator did not know how to understand the Hebrew text, he may have relied instead on a contemporary sense of the written word or a similar word from his own spoken language. ${ }^{106}$ Gentry discusses the example of Ps 60:10 (paralleled in 108:10), where the OG renders רֵַ, "washing," with

period of time." Ghormley, "Scribal Revision: A Post-Qumran Perspective on the Formation of Jeremiah."

104 See Tov, Text-critical Use of the Septuagint, 179; Aejmelaeus, On the Trail, 80.

105 For example, Emanuel Tov, The Greek and Hebrew Bible: Collected Essays on the Septuagint (Leiden: Brill, 1999), 203-218; Tov, Text-critical Use of the Septuagint, 178-83; Glenny "Hebrew Misreadings or Free Translation," 534-43; Anthony Gelston, "Some Difficulties Encountered by Ancient Translators," in Sôfer Mahîr: Essays in Honour of Adrian Schenker Offered by the Editors of Biblia Hebraica Quinta, eds. Yohanan A. P. Goldman, Arie van der Kooij, and Richard D. Weis, VTSup 110 (Leiden: Brill, 2006), 47-58; Barr, Comparative Philology, 249, 253-54, $266-67$.

106 See, for example, Jan Joosten, Collected Studies on the Septuagint: From Language to Interpretation and Beyond, FAT 83 (Tübingen: Mohr Siebeck, 2012), 53-66, 67-80; Jan Joosten, "The Knowledge and Use of Hebrew in the Hellenistic Period: Qumran and the Septuagint," in Diggers at the Well: Proceedings of a Third International Symposium on the Hebrew of the Dead Sea Scrolls and Ben Sira, eds. Takamitsu Muraoka and John F. Elwolde, STDJ 36 (Leiden: Brill, 2000), 115-30; GoshenGottstein, "Theory and Practice," 140; Seulgi L. Byun, The Influence of Post-biblical Hebrew and Aramaic on the Translator of Septuagint Isaiah, LHBOTS 635 (London: Bloomsbury, 2017). We should keep in mind, however, that importing meaning from related words and "manipulating the Hebrew consonants" could have been an intentional strategy for interpreting the text; quote from Tov, Greek and Hebrew Bible, 210, and see 211-13; and see Arie van der Kooij, review of Seulgi L. Byun, The Influence of Post-biblical Hebrew and Aramaic on the Translator of Septuagint Isaiah, in RBL 2017 [http://www.bookreviews.org]. It is also worth noting that translators were not alone in this sort of engagement with the text in interpretation; see Teeter, Scribal Laws. 
$\dot{\varepsilon} \lambda \pi i$, "hope." 107 Though OG Psalms is fairly consistent in using $\dot{\varepsilon} \lambda \pi i ́ \zeta$ for nouns and nominals of the roots ("to trust") and ("to take refuge"),

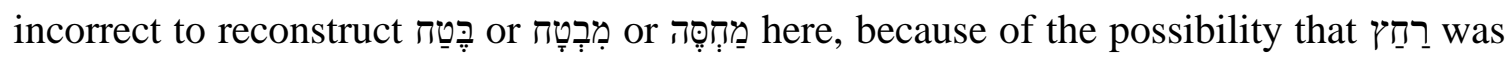
read via Aramaic $\bigvee_{\curlyvee}$, "to trust." While a scribe could have experienced the same pressures as a translator to read the word according to his vernacular language, it is probable that he would have left the word as in his Vorlage. That being said, we should also consider the possibility that a scribe glossed or replaced the word with something like מִבְטָָה. A scribe, while having the option of rote copying, still may have attempted to make sense of the text and change the text on that basis. When, for example, the scribe of 1QIsa added the gloss ברזל, "iron," just before ("brier and thorn") in Isa 7:25, it was a result of misunderstanding the Hebrew text-in his vernacular Hebrew שמיר could mean "iron"- and attempting, incorrectly, to clarify the text for future readers. ${ }^{109}$ Therefore we should be careful not to assume that translators were the only ones who could misunderstand the text, and we should always ask whether a change in the text could have been made by a scribe in Hebrew. ${ }^{110}$

As I argued above and elsewhere, variants arising because of the translator and variants arising in his Vorlage are, for the most part, indistinguishable within isomorphic passages of the OG. Most of the times where we can tell the two apart is when the translation reflects an attempt to make sense of a difficult text. A scribe who did not understand had two options - change the text or pass it on through rote copy-but a translator had, for the most part, just one option. ${ }^{111}$ Therefore, such variants are more likely to stem from translation.

\subsection{Proceed to HB Textual Criticism}

After the steps above are taken, a Hebrew retroversion can be used in HB textual criticism. I would reiterate that, according to my approach, we do not need to ask whether the OG translator has committed scribal error, changed the text based on his decoding or interpretation of the text, or changed the text deliberately for some theological or other purpose. Questions of this order can be asked of all the Hebrew readings - retroverted and from Hebrew manuscripts - within the process of HB textual criticism.

107 Gentry, "The Septuagint and the Text of the Old Testament," 200-201.

108 Hatch-Redpath, s.v. غ̇ं $\pi$ ís.

109 Tov, Textual Criticism, 260.

110 As Tov notes, our tendency is to give "more credit ... to Hebrew scribes than to ancient translators" (Text-critical Use of the Septuagint, 183), whether with respect to the textual and literary coherence of readings, to which Tov refers, or knowledge of ancient Hebrew and difficult phrases in the Hebrew Bible.

111 While the OG could, and sometimes did, resort to transliteration, which is in some ways as close to rote copy as the OG could get, this was probably a less often used strategy in translation than rote copy was in transmission. Cf. Aejmelaeus, On the Trail, 80. 


\section{Conclusion}

The approach I suggest above does not alleviate the central difficulty of using the OG for HB textual criticism: we will never be certain how many, or whether any, of the OG variants established through this or another approach were created by the translator rather than his Vorlage. To jettison the data in its entirety, however, would be to throw the champagne out with the cork. Previous approaches emphasize the ways in which OG evidence may derive from the translation process, assuming that data is translationrelated until proven otherwise. In particular, "interpretive" and "exegetical" changes to the text are taken as disqualifiers, even though we know that scribes made the same changes to the text in Hebrew. In contrast, my approach begins with the assumption that the OG, when isomorphic, reflects a Hebrew Vorlage, unless it can be proven otherwise. This approach allows us to use more evidence in the endeavor of HB textual criticismand we sorely need it. ${ }^{112}$ "One simply has totoaccept the fact that some reliable retroversions never existed in writing."

112 Cf. Screnock, Traductor Scriptor, 181.

113 Tov, Text-Critical Use of the Septuagint, 178. 